THE URBAN TRANSPORT CRISIS IN EUROPE AND NORTH AMERICA 



\section{The Urban Transport Crisis in Europe and North America}

\section{John Pucher}

Associate Professor of Urban Planning

Rutgers University

and

Christian Lefèvre

Associate Professor of Urban Studies

Institut d'Urbanisme de Paris

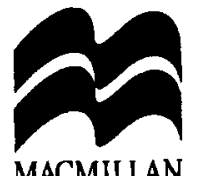

MACMILLAN 
DOI $10.1057 / 9780230371835$

(C) John Pucher and Christian Lefevre 1996

Reprint of the original edition 1996

All rights reserved. No reproduction, copy or transmission of this publication may be made without written permission.

No paragraph of this publication may be reproduced, copied or transmitted save with written permission or in accordance with the provisions of the Copyright, Designs and Patents Act 1988, or under the terms of any licence permitting limited copying issued by the Copyright Licensing Agency, 90 Tottenham Court Road, London WIP 9HE.

Any person who does any unauthorized act in relation to this publication may be liable to criminal prosecution and civil claims for damages.

First published 1996 by

MACMILLAN PRESS LTD

Houndmills, Basingstoke, Hampshire RG21 6XS

and London

Companies and representatives

throughout the world

ISBN 978-0-333-62795-2 hardcover

ISBN 978-0-333-65551-1 paperback

A catalogue record for this book is available from the British Library.

$\begin{array}{llllllllll}10 & 9 & 8 & 7 & 6 & 5 & 4 & 3 & 2 & 1\end{array}$

$\begin{array}{llllllllll}05 & 04 & 03 & 02 & 01 & 00 & 99 & 98 & 97 & 96\end{array}$ 


\section{Contents}

List of Tables and Figures viii

Preface $\quad$ xi

List of Acronyms xiv

1 The Urban Transport Crisis: An Introduction 1

Objectives of the Book $\quad 2$

Organization of the Book $\quad 3$

2 Overview of Urban Transport Systems and Land Use

Patterns in Europe and North America $\quad 7$

Problems of Data Reliability and Comparability $\quad 8$

Basic Demographic Trends 9

Trends in Travel Behaviour $\quad 12$

Trends in Urban Land Use Patterns $\quad 21$

Urban Transport Problems $\quad 23$

Government Transport Policies $\quad 27$

Conclusions $\quad 41$

3 Germany: The Conflict between Automobility and

Environmental Protection $\quad 43$

Trends in Travel Behaviour $\quad 44$

Urban Land Use Patterns $\quad 48$

Urban Transport Problems $\quad 50$

Urban Transport Policies $\quad 56$

Conclusions $\quad 64$

4 France: The Impossibility of Accommodating the Car and Public Transport in Transport Policies 65

Urban Spatial Structure $\quad 66$

Trends in Urban Transport: The Dominance of the Car and the Erosion of Public Transport $\quad 67$

The Urban Transport Crisis $\quad 71$

Policies Designed to Deal with these Issues 75

$\begin{array}{ll}\text { Conclusion } & 82\end{array}$ 
5 The Netherlands: A Wise Country Overtaken by World

Trends

Urban Spatial Structure

Trends in Urban Transport $\quad 88$

Urban Transport Problems $\quad 93$

Transport Policies $\quad 94$

Conclusion $\quad 99$

6 Italy: Cities without Policies $\quad 101$

Trends in Urban Spatial Structure $\quad 101$

Trends in Urban Travel Behaviour $\quad 102$

The Urban Transport Crisis 106

The Political Inability to Implement Policies $\quad 110$

$\begin{array}{ll}\text { Conclusion } & 115\end{array}$

7 Great Britain: Failure of Free Market Policies 117

Trends in Urban Spatial Structure $\quad 117$

Trends in Urban Transport $\quad 119$

Urban Transport Problems $\quad 124$

Transport Policies $\quad 126$

$\begin{array}{ll}\text { Conclusion } & 137\end{array}$

8 Eastern Europe: Transport Impacts of Political

Revolution

138

Urban Transport under Socialism 139

Urban Transport after the Fall of Socialism 142

Urban Land Use Patterns $\quad 148$

Urban Transport Problems $\quad 149$

Conclusions and Policy Implications 154

9 Canada: Bridge between Europe and the United States 159

Trends in Urban Spatial Structure $\quad 160$

Trends in Travel Behaviour $\quad 162$

Urban Transport Problems $\quad 165$

Urban Transport Policies $\quad 168$

$\begin{array}{ll}\text { Conclusions } & 173\end{array}$

10 The United States: The Car-Dependent Society 175

Trends in Urban Spatial Structure $\quad 176$

$\begin{array}{ll}\text { Trends in Urban Transport } & 178\end{array}$

$\begin{array}{ll}\text { Urban Transport Problems } & 183\end{array}$ 
Urban Transport Policy

11 Dealing with the Urban Transport Crisis: Comparative Policy Evaluation

Inadequate Policy Responses

Improving Transport Policy: What Can Countries Learn* from Each Other? 


\section{List of Tables and Figures}

\section{Tables}

2.1 Population, population change, density and rate of urbanization in selected countries, 1970-92

2.2 Per capita income and car ownership in selected countries, 1992

2.3 Vehicle km of car use per capita, 1970-92

2.4 Modal split (as percentage of total trips) in urban areas, 1990

2.5 Modal split in selected urban areas (as percentage of total trips)

2.6 Public transport trips per inhabitant per year in selected urban areas

2.7 Traffic fatality rates in selected countries, 1970-92

2.8 Fare recovery ratio in urban public transport in selected countries

2.9 Fare recovery ratio in selected urban areas

2.10 Status of ownership of urban public transport companies in selected countries

2.11 Who is responsible for urban public transport in selected countries?

3.1 Trends in population, car ownership and use, 1950-92 45

3.2 Trends in car travel and public transport use, 1950-92 46

3.3 Modal split trends for urban travel in West Germany, 1976-89

3.4 Modal split trends for urban travel in East Germany, 1972-91

4.1 Population evolution by type of urban area, 1975-90 66

4.2 Population evolution in the 10 largest urban areas, 1982-90

4.3 Change in modal split in Grenoble and Bordeaux urban areas

4.4 Annual changes (per cent) in public transport use, 1975-93 70

4.5 Fare recovery ratio in public transport, 1975-93

5.1 Percentage distribution of travel by trip purpose, national aggregate (as percentage of total travel), 1980-92 
5.2 Modal split in four Dutch urban areas (1986-90 travel surveys) and in other urbanized areas

5.3 Evolution of modal split according to the average trip distance, 1980-90

5.4 Urban transport usage changes, 49 major cities, 1981-92 92

5.5 Public transport deficit, 1981-92

6.1 Population change in the largest Italian metropolitan areas, 1971-87

102

6.2 Evolution of modal split in urban areas, 1984-90 103

6.3 Modal split in four urban areas in $1990 \quad 104$

6.4 Population (in 1000) and number of cars (in 1000), 1970-92

104

6.5 Car ownership, $1986 \quad 105$

6.6 Urban public transport usage, 1981-91 106

6.7 Fare recovery ratio of various local public transport modes, 1985-91

6.8 Operating deficits of urban bus networks by region, 1990

7.1 Population size (in 1000) and change (in per cent) in the largest urban areas, 1971-91

7.2 Change in modal split, London, 1975-91

7.3 Change in modal split, urban areas, 1985-91

7.4 Main mode of travel to work by area of residence in London, 1971-91

7.5 Changes in local public transport usage in metropolitan areas, 1975-92

7.6 Household car ownership in urban areas, 1976-91, and in London (1971-91)

7.7 Percentage change in local bus-kilometres run, 1985-86 to $1991-92$

7.8 Percentage change in local bus passenger journeys by area, 1985-86 to $1991-92$

7.9 Types of services registered, 1991-92

7.10 Local bus services, fare indices by area, 1984 to 1991-92

8.1 Trends in car ownership in Eastern and Central Europe, 1970-2000

8.2 Trends in public transport usage in Eastern and Central Europe, 1980-92

8.3 Trends in public transport's share of urban travel in Eastern and Central Europe, 1970-92 
9.1 Trends in population and car ownership, 1951-91 162

9.2 Public transport usage trends, 1950-92 163

9.3 Modal split shares and per capita rates of public transport use in selected Canadian metropolitan areas

9.4 Public transport subsidies (in Canadian \$), unprofitability and productivity, 1970-92

9.5 Public transport funding, 1970-92

9.6 Variations by province in government funding of public transport subsidies, 1992

10.1 Modal split trends in urban travel, 1969-90

179

10.2 Modal split distributions for work trips in the 20 largest metropolitan area, 1990

10.3 Trends in population and car ownership, 1960-90 181

10.4 Trends in urban public transport usage, 1950-92 181

10.5 Trends in supply and demand for urban roads versus public transport, 1970-92

10.6 Trends in government subsidy support for roads versus public transport, 1970-92

10.7 Traffic fatalities, 1960-92 187

10.8 Energy efficiency of cars, 1960-92 188

\section{Figures}

2.1 Car ownership rate in selected countries, 1970-92

2.2 Change in public transport usage in selected countries, 1970-92

7.1 Saturated railway lines in the London area 


\section{Preface}

This book represents the culmination of the authors' many years of research on urban transport. Pucher began studying American transport policy in 1975, with emphasis on the efficiency and equity impacts of subsidies. Since 1984, his efforts have focused on comparative analysis of transport policies in Europe and North America. Lefèvre's interests have also been in comparative policy analysis but, in contrast to Pucher's economic focus, Lefèvre has concentrated on political and institutional issues. The two approaches complement each other. The book offered the authors an opportunity to update their previous analyses, extend them to more countries, and compare them with each other's different range of experiences. Thus, the authors were able to learn a great deal themselves in the process of writing this book.

The listed order of authorship was chosen at random and has no implication for the relative contributions of each author. Although the idea for the book and its approximate content was joint, each author focused his effort on the subject area of the book closest to his own interests and knowledge. Thus, Pucher wrote the four chapters on the USA, Canada, Germany and Eastern Europe. Lefèvre wrote the four chapters on Italy, France, Great Britain and The Netherlands. Overall, however, the book represents a genuine collaboration, with both authors involved in determining the structure of the book and individual chapters, data assembly and analysis, and policy evaluation.

The authors are deeply indebted to a great number of individuals and institutions for their assistance in obtaining information essential to writing the book. Each author would like to thank in turn those who helped. For the chapter on Germany, Pucher thanks the German Ministry of Transport, the German Association of Transport Firms (especially Mr Wergles), the German Institute of Economic Research (Dr Kunert), and many individual public transport systems for essential data and advice. In addition, he is deeply indebted to the transportation institutes at the University of Muenster and the Technical University of Dresden which hosted Pucher for extended periods to do research on German transport. The Humboldt Foundation of the German Federal Government funded Pucher's research on Germany and Eastern Europe. For the chapter on Eastern Europe, Pucher thanks the Polish, Czech, German and Hungarian ministries of transport for providing extensive assistance. Moreover, 
colleagues at universities in Dresden (Professors Voigt, Ackermann, Foerschner), Prague (Dr Klofac and Professors Sykora and Cepek), Budapest (Professor Koller) and Warsaw (Dr Rataj, Dr Kocon, Professors Suchorzewski, Lijewski and Weglenski) greatly facilitated the research on Eastern Europe by offering data, analysis, and friendship. The US Department of Transportation and the American Public Transit Association were the most important sources of information for the chapter on the USA. In addition, the US Department of Transportation funded several of Pucher's research projects between 1980 and 1990, which yielded information for the chapter. The Canadian Urban Transit Association, Statistics Canada and Transport Canada provided most of the data for the Canada chapter. Pucher is especially indebted to colleagues in Calgary (Professor Perl), York (Professor Turritin), and Toronto (Dr Gurin, Dr Cormier, Dr Hemily and Dr Dunbar) for providing much information, analysis and advice.

For the chapter on France, Lefèvre thanks his colleague Dr Offner in the LATTS (Laboratoire des Techniques, Territoires et Société) and various institutions such as the French Ministry of Transport, Centre d'Etudes des Transports Urbains (CETUR), Institut National de Recherche sur les Transports et leur Sécurité. (INRETS), Groupement des Autorités Responsables des Transports (GART) and Union des Transports Publics (UTP) for their advice and assistance. For the chapter on Italy, Lefèvre thanks Professor Podesta (Politecnico di Milano) and the Centro Studi Sui Sistemi di Trasporto (in Rome) for their comments on the draft version. He would also like to thank those who aided his research on transport in Milan area: Mr Anselmetti (of the regional government), Mr Minotti (of the Milan planning agency), Mr Spatti (of the Regional Railways), and Mr Tarulli (of the Istituto Regionale di Ricerca dello Combardia). For the UK, Lefèvre thanks Professor White (University of Westminster) for his useful suggestions on improving various drafts of the chapter, and also the staff of the Transport and Road Research Laboratory (TRRL) and the Greater Manchester Transport Executive. For the Netherlands, Lefèvre thanks Mr Baanders in the research division of the Dutch Ministry of Transport and Professor Jansen (Institute of Spatial Organization in Delft).

Both authors would like to thank the European Conference of the Ministers of Transport (ECMT) and the International Union of Public Transport (UITP), especially its General Secretary, Pierre Laconte, for their overall assistance throughout the writing of this book. They provided extensive data directly and also facilitated contacts with individual ministries of transport, transport associations and particular public trans- 
port systems. Bo Peterson (of AB Storstockholms Lokaltrafik) provided supplemental information on the situation of public transport in Sweden.

JOHN PUCHER

Christian LefÈvRE 


\section{List of Acronyms}

$\begin{array}{ll}\text { ATM } & \text { Azienda Trasporti Municipali } \\ \text { BR } & \text { British Rail } \\ \text { CETUR } & \text { Centre d'Etudes des Transports Urbains } \\ \text { CNT } & \text { Conto Nazionale dei Trasporti } \\ \text { DB } & \text { Deutsche Bundesbahn } \\ \text { DoE } & \text { Department of the Environment } \\ \text { DOT } & \text { Department of Transport } \\ \text { ECMT } & \text { European Conference of the Ministers of Transport } \\ \text { EU } & \text { European Union } \\ \text { FNM } & \text { Ferrovie Nord Milano } \\ \text { FNT } & \text { Fondo Nazionale dei Trasporti } \\ \text { FS } & \text { Ferrovie dello Stato } \\ \text { GART } & \text { Groupement des Autorités Responsables des Transports } \\ \text { GLC } & \text { Greater London Council } \\ \text { HOV } & \text { High Occupancy Vehicle } \\ \text { INRETS } & \text { Institut National de Recherche sur les Transports et leur } \\ & \text { Sécurité } \\ \text { INSEE } & \text { Institut National de la Statistique et des Etudes Economiques } \\ \text { IRF } & \text { International Road Federation } \\ \text { ISTEA } & \text { Intermodal Surface Transportation and Efficiency Act, 1991 } \\ \text { IVHS } & \text { Intelligent Vehicle Highway System } \\ \text { LBL } & \text { London Bus Ltd } \\ \text { LOTI } & \text { 1982 Law on domestic transport } \\ \text { LRT } & \text { Light Rail Transit } \\ \text { NBC } & \text { National Bus Company } \\ \text { NS } & \text { Nederlandse Spoorswegen } \\ \text { NTS } & \text { National Travel Survey } \\ \text { OECD } & \text { Organisation for Economic Cooperation and Development } \\ \text { PDU } & \text { Plan de Déplacements Urbains } \\ \text { PTA } & \text { Passenger Transport Authority } \\ \text { PTC } & \text { Passenger Transport Company } \\ \text { PTE } & \text { Passenger Transport Executive } \\ \text { PTU } & \text { Périmètre de Transport Urbain } \\ \text { RATP } & \text { Régie Autonome des Transports Parisiens } \\ \text { RIF } & \text { Région Ile de France } \\ \text { SBG } & \text { Scottish Bus Group } \\ & \end{array}$


TGV Train à Grande Vitesse

TRRL Transport and Road Research Laboratory

TSM Traffic System Management

UITP International Union of Public Transport

UTP Union des Transports Publics

VAL Véhicule Automatique Léger

VDV Verband Deutscher Verkehrsunternehmen

VT Versement Transport 